\title{
Sociological Theories of Intervention. Psychosociological and Microsociological Approaches
}

\author{
Bernardeau-Moreau \\ Correspondence: Univ. Lille, ULR 7369, Unité de Recherche Pluridisciplinaire Sport Santé Société (URePSSS), Lille, \\ F-59000, France
}

Received: November 21, 2021 Accepted: February 3, 2022 Online Published: February 16, 2022

doi:10.5539/res.v14n1p28

URL: https://doi.org/10.5539/res.v14n1p28

\begin{abstract}
A range of scientific works show that sociological intervention is rooted in two main theoretical branches psychosociology and microsociology. Although the concepts and foundations of these two major scientific branches are, of course, different, their relationships with the subject mix proximity and self-analysis, resulting in an enlightening common factor. Our intention with this article is not only to identify the primary theories and concepts developed over the past two centuries, but also, and above all, to be able to look beyond their unique features to better visualize the probable points of convergence so as to provide a coherent framework that unifies the different psychosociological forms of intervention.
\end{abstract}

Keywords: sociological intervention, psychosociology, microsociology, procedural methodology

\section{An Introduction to Sociological Intervention}

A range of scientific works (Alinsky, Colley, Dubet, Dubost, Herreros, Savoye, Stonequist, Wieviorka) show that sociological intervention is rooted in two main theoretical branches - psychosociology and microsociology. Although the concepts and foundations of these two major scientific branches are, of course, different, their relationships with the subject mix proximity and self-analysis, resulting in an enlightening common factor. The concept of intervention and its initial forms of theorization were supported in particular by American psychosociology from the 1940s, then the French school of thought 30 years later. Lewin and his method of action research, the works by the Tavistock Institute, Jacques and socio-analysis, and even Moreno and sociometry, were precursors. These works had a significant response in France, thanks to researchers in psychosociology and clinical sociology, such as Pagès, De Gaulejac and even Dubost. In terms of microsociology, it is useful to place sociological intervention in the general history of social sciences. Starting from this point, with Savoye (1979) and Hess (1981), it is possible to place the origins of sociological intervention in the monographic microsociology of Le Play, which was adopted by empirical American sociologists, then given new momentum in Europe by Lapassade's institutional analysis, Touraine's method of sociological intervention and Crozier's strategic analysis (Chapoulie 2012, Herreros 2012). Our intention with this article is not only to identify the primary theories and concepts developed over the past two centuries, but also, and above all, to be able to look beyond their unique features to better visualize the probable methodological points of convergence so as to provide a coherent framework that unifies the different psychosociological forms of intervention.

\section{Material and Method}

For this study, we carried out a long documentary and historical research (Ghiglione \& Matalon, 1998), based on the reading of the main books, book chapters, articles and conference acts analyzing the sociology of intervention in its psychosociological and microsociological approaches. This research on a corpus of literature (Singly, Giraud \& Martin, 2011) allowed us to build a synthesis by similarities and then a comparative analysis of the different theories proposed by their authors. These successive methodological steps then allowed us to propose a coherent explanatory framework by distinguishing the elements of divergence and convergence of the different theoretical and methodological frameworks (Chapoulie, 2005).

To present this research, our article is divided into four sections. The first aims to give context to the main stages of creating sociological intervention, from Le Play's monographic works to Marx's self-reflective analysis. The second addresses the psychological aspect of intervention, mentioning works by Lewin, Tavistock and other authors, such as Jaques and Moreno. The goal is to outline the elements that characterize psychosociological intervention and to recall the primary scientific sources that have driven the various branches of social psychology linked to the position of the researcher when faced with their subject(s). The third section aims to create a link between Le Play's monographic study 
and the Chicago School's empirical sociology. It also questions the place of sociology among the agents/actors in the situation. In the last section, we focus primarily on the methods that concretize the intervention. The different stages of intervention illustrate its procedural nature. In the conclusion, we discuss the purpose of sociological intervention, including unique analysis and increase in generality.

\section{The Stages of Creating the Intervention}

Determining the interventional origins of sociology has proven to be a perilous, even impossible, operation as intervention is a part of sociology (Cabé 2016, Bucolo \& Haeringer 2018). Whether from nearby or a distance, when sociologists observe, question and quantify data to understand a group or a social situation, they are intervening. It is often the case that they are asked to explain their approach or present their results to actors in sociology. Dubet highlights that in sociology, "intervention is a fact most of the time" (2001, p. 90). However, this intervention has varying degrees of significance and is used to differing extents depending on the sociologist's level of detachment. The author adds that in reality, between sociology and intervention, "everything is a matter of degrees" (Ibid.). Of the sociologists who have really cultivated a close relationship with the subjects studied, two stand out: Frédéric Le Play, who is known for his many, and meticulous, monographs, and Marx, whose studies of the working class formed the foundations of sociology of knowledge.

\subsection{The Monographic Origins of Intervention}

With his quasi-empathetic sociological approach to the groups he studied, Frédéric Le Play broke with the positivist tradition of sociology. At a time when the scientific and institutional foundations of the discipline appeared to still be fragile, Le Play developed a monographic methodology that exposed him to criticism from the dominant branch of sociology. His monographic investigations into the social organization of miners in Oberharz in northern Germany (1829), carpenters in Paris (1856), roofers and glazers in Savoie (1857) and bakers in Paris (1859) were carried out using precise investigation tools (observation frameworks, counting and inventory forms, interviews and life stories). Le Play (followed by Tourville and Cheysson) came to systematically use direct observation. His hypothesis was to consider that the state of a society may be subject to analysis based on the direct study of a microsocial unit. This unit embodies, in one way, the society in miniature and thus makes it possible to understand one by learning about the other in a mirror effect. For Le Play, it was through direct observations that general inductions could be drawn (Le Play, 2000, p. 206). It is also with regard to this point (note that we found the same criticisms for sociological intervention as a whole) that the monographic approach will trigger the most reservations in the scientific community. Sociologists such as Durkheim and Worms were open about their skepticism because to them, it seemed difficult to perform sufficiently general analyses to enable better comprehension of a society in its entirety on the basis of results obtained that are specific to a particular situation. Worms wrote that "we will be led to doubt that the data relating to one family, one workshop, or even one municipality considered in isolation can be extended to an entire society" (1918, p. 124). It is because it focuses on case studies and on unique situations that a group of academic sociologists contest the position of intervention, which they believe prevents an increase in generality and allows for descriptions, but not explanations. This criticism has several justifications when we take into account that Le Play sometimes tended to fall into a simplistic and black-and-white interpretation lauding the traditional Catholic family. However, limiting sociological intervention to only one descriptive dimension appears very reductive. Following Le Play, Tourville strove to respond to criticisms by trying to develop a glossary of social phenomena. Although the use of monographic investigations is not entirely new (Parent-Duchatelet carried out monographs on prostitution in 1836, Tristan on the English proletariat in 1840 and Focillon on soap makers in 1859), Le Play was the first to implement systematic use by opting for microsociology based on in-depth study of concrete facts observed from within social situations. Other sociologists, such as Mendras, subsequently highlighted the use of Le Play's works while confirming the need to reconcile monographic analysis and statistical study to develop theoretical models (Mendras, 1975, p. 15).

\subsection{Marx's Self-Administered Study of the Working Class}

Another pioneering thinker in self-reflective sociology (although he was also very radical), Marx was heavily influenced by 18th-century philosophers, especially Saint-Simon and Proudhon. He showed his opposition to and skepticism of Comte's positivist thinking and recognized the benefit of a social science for the proletariat at a very early stage. In his famous quote - "It is not the consciousness of men that determines their being, but, on the contrary, their social being that determines their consciousness." (1859, p. 272) - Marx called for awareness among the ruling classes as a precursor to change to the social system. By denying all natural law that would organize social life, he developed the idea that society is only the product of human actions through their exchanges. He therefore brought legitimacy to a "general theory of social production by humans themselves in their reciprocal relationships" (Simon, 1991, p. 238). In 1880, Marx published a very illuminating survey for the working class in La Revue socialiste. This was a questionnaire aimed at workers and therefore self-administered by them. Marx worked on the assumption that workers are the only people who are able "to 
describe, in full knowledge of the cause, the ills that they endure" (extract from the introduction letter of the questionnaire published in La Revue socialiste). What made Marx's approach original is that it favored open questions (in that time, the norm was to have respondents check boxes), leading workers to reflect on their conditions and to put their ills into words in some way. It should be noted that this questionnaire was politically motivated because it aimed to compare the situations for workers and employers.

Through their works and original positions, Le Play and Marx contribute to rethinking the methods of implementing social sciences. Other authors, such as Weber and Simmel, highlighted the importance of maintaining close contact with individuals in the perspective of comprehensive sociology. The dominant branch of sociology's trend of separating pure research and applied research, leading to a dichotomy between knowledge and action (Chapoulie, 2012), has given rise to a generation of researchers who are mindful of a more psychological interpretation that makes the subject more accessible to society.

\section{A Psychological Interpretation of Intervention}

\subsection{Action Research: Necessary Closeness Between Researchers and Subjects}

The psychological nature of intervention has its roots in the group dynamic developed by Lewin in the $1940 \mathrm{~s}^{1}$ within the Research Center for Group Dynamics, which he led until he passed away in 1947. Inspired by Gestalt theory, Lewin became interested in the social group as an entity that goes beyond simply the amount of people therein. This led him to identifying structural properties, meaning properties that, through the interplay of dynamic relationships, show that one part in the whole is different to an isolated part (Lewin, 1946). Lewin connected research with action to report on these structural properties. He believed that it was not possible to discover the social reality without acting on it and that observation and classification alone were insufficient. He explained that the situation has to be changed to understand its motivations. Lewin carried out one of his first studies during wartime, in which he researched methods of changing the eating habits of American households. The goal driving Lewin and his team was to encourage greater proximity between the actors who have to be part of collaborative research at all times and to develop the means of improving their situation with experts, step by step. Action research therefore involves an essential interventionist aspect in which the sociologist looks to measure the gaps and differences between theory and practice, between what is said and what happens, between how individuals imagine things to be and how they actually are. These gaps carry meaning for the researcher and also for the actors in the situation. Action research is therefore part of a "participative approach to change" (Liu, 1997, p. 34). For psychosociologists, intervening means acting within a social organization as required and with a view to facilitating its change. All of these clinical and psychosociological theories thus have a common foundation with all intervention practices: they seek to spark awareness among the group itself by using an inductive method and somewhat empirical position in order to enable it to develop autonomy and an ability to manage its conflicts.

Although action research has undergone very varied developments, despite its founder's efforts, this is because it remains a very fluid concept, as there are many, wide-ranging ways of linking research and action. Action research represents a combination of practices and procedures aiming to bring together knowledge and action with a view to changing a situation, behaviors and attitudes to, in short, "ensure that individuals better adapt or integrate into their environment" (Franck, 1981, p. 161). The association of the two words "action" and "research" may seem ambivalent and ambiguous. In reality, the two approaches are complementary, but with different impacts. As explained by Resweber, "in short-term interventions, it is the action that sparks, leads and finalizes the research. In long or medium-term interventions, it is research that leads to action" (1995, p. 5). Therefore, a "dialectic relationship" (Ibid.) is established between the research and the action, between the theory and practice and between the acting individual and the thinking individual. However, this dialectic relationship evolves over a scale with varying degrees depending on the survey conditions, which is not conducive to a precise definition of the action research or actual consensuses among researchers. If there is a consensus, it raises more concepts and positions than a sociological theory, strictly speaking.

\subsection{The Collaborative Analysis of Psychosociologists}

Lewin's works went on to have considerable influence on the Tavistock Institute, which was founded in London by Emery and Trist. After Lewin's sudden death, the Tavistock researchers continued his studies, but their concept of the roles of researchers and actors differed slightly from that of Lewin. For Lewin, researchers were the only study leaders and the actors were unable to participate in the research. The mindset driving Tavistock was a bit different. It advocated collective participation with all actors in the field. These researchers were concerned with offering a collaboration that allows actors to manage it themselves. This was the case for Eliott Jaques, a former Tavistock member, who developed the

\footnotetext{
${ }^{1}$ However, the origins of action research remain disputed. Some sociologists recognize the origins of action research in Dewey (Barbier, 1996, p. 15). Others, such as Lapassade, attribute its roots to anthropologist Collier in his studies of Native Americans.
} 
socio-analysis method by examining the Glacier Metal Company (1948-1950). He studied the interactions between social structures (roles, authority systems) and mental structures (fantasies, obstacles, anxieties). Introducing psychoanalysis when analyzing organizations and rejecting an approach considered too technocratic, the author advocated collaborative research for social therapy purposes: He wrote that "The nature of institutions is determined and influenced not only by their functions, whether explicitly or consciously agreed by common agreement, but also by their many unrecognized functions, on a phantasmatic level." (Jaques, 1968, p. 549). In his opinion, the researcher has to develop a transfer process that aims to convert negative feelings into positive feelings. This "working through" (meaning looking to remove oppositions) consists of leading individuals to become aware of their opposing behavior (a type of irrational anxiety) in order to overcome them. The psychotherapeutic direction of action research studies is illustrated by other studies published by researchers who were peers of or successors to Lewin. Moreno illustrated this in his works on sociometry in the 1940s. By aiming to analyze social groups in vivo, like co-actors participating in their everyday life (Dubost \& Levy, 2016, p. 412), he developed a therapeutic approach with a view to restoring the hidden nature of psychodramas experienced by individuals in interrelationships. The goal of the sociometry tests was therefore to highlight affinities and antipathies, real and informal feelings that regulate interpersonal relationships. Moreno's work was continued, in particular, by Lazega in his analysis of social networks. These works had a significant response in France thanks to researchers such as Pagès, De Gaulejac and even Dubost. The clinical sociology that was developed in the 1990s by Enriquez and De Gaulejac led to the sociological purpose being directed at the subject. Clinical sociology "proposes concentrating on the clinical approach to understand social phenomena, which constitutes a particular method of carrying out research and interventions. It means working as close as possible to the experience of actors" (De Gaulejac et al., 2012, p. 25). This form of sociology is included in Weber's branch of comprehensive sociology by looking to go beyond the heuristic end. The clinician attempts to make the subject conceptualize their experience. Clinical sociology proposes reintegrating the subject and subjectivity in the same purpose of sociology by looking past disciplinary obstacles between psychology and sociology.

Pagès writes that psychosociology is entirely concerned with being useful to those it studies. Its objective is not to propose goals to the organization, but to "prepare (the actors) to take charge of their everyday life" (Petit, 1989). According to psychosociology, "social speech" has an essential role (Lapassade, 2006, p. 63). Through the proximity that it creates between researchers and individuals and through its desire to have social actors actively participate in improving their local situation, psychosocial analysis has led some sociologists, such as Herreros, to confirm the strong likeness between the action research and general practices of intervention. While it is psychological in its approach, action research appears to complement sociological analysis.

\section{The Microsociological Approach of Social Situations}

Sharing the idea of social change and reform, sociologists from the Chicago School have continued the monographic works by Le Play. They cultivated a pragmatic position and a keen interest in society's concrete problems and applied microsociology based on several monographic surveys and participant observations using the most rigorous methodology. With its population boom, the urban environment of Chicago became a prime location for sociological research conducive to the development of a sociology of deviance. The work published by Small in 1894 with Vincent - "Introduction to the study of society" - includes, in particular, two chapters dedicated specifically to empirical methods in sociology. Taking into account that "the method of Le Play is the line of departure for some of the most zealous and intelligent social investigators" (Small \& Vincent, 1894, p. 48), Small calls for the use of active research that involves sociologists in the area of investigation. By defining the concept of the looking-glass self, Cooley looked to explain how the process of socialization is built around the way that each individual thinks they are seen and perceived by others. According to the American sociologist, it is not possible to understand the social world without understanding the major role played by social interaction in the process of self-identification. These different authors (including also Burghardt Du Bois) worked to develop microsociology by concentrating their research on limited groups (districts, small towns, communities) with considerable integration problems linked to immigration, alcoholism, drugs and poverty. For them, the sociological approach consisted of placing the researcher and the social agent side-by-side, rather than one above the other, in such a way that the individual experience drives the understanding of society in a collaborative manner. Following on from Le Play, these sociologists also noted the starting point of an empiricist tradition that is characteristic of the origins of American sociology. However, it should be noted that the nature of American sociology is not the result of solely these first empiricists. Other authors from varied intellectual and philosophical branches made their own contributions. For the pragmatist Dewey, reality is to carry out research in its real and measurable consequences in the social world. For Mead, relationships are built through the interplay of interpretations and symbols that bring together and drive apart individuals. As successors to Small and Cooley, Thomas and Park published their studies of the general public, which contained an abundance of life stories and very detailed biographies, while Burgess consolidated the foundations of urban sociology. All of them draw on social Darwinism in an attempt to describe and understand the forms of social adaptation, 
acculturation, disorganization and reorganization implemented by migrants in a rapidly expanding urban environment. They show that the existence and lifestyles of social groups and subgroups are only responses and coping strategies to a difficult, sometimes violent social environment. Alongside Znaniecky, Thomas published a significant five-volume work on the conditions of Polish farmers in Europe and the United States, using a qualitative method based on biographies and life stories. Other monographs were carried out in the same era, such as Anderson's study of "hobos" in 1923, Wirth's study of Jews in 1925, Thrasher's study of gangs in 1927, Zorbaugh's work on the residents of trendy areas in 1929, Cressey's study of taxi dance halls in 1932, Stonequist's work on "the marginal man" in 1937, Shaw and Mc Kay's study of juvenile delinquency in 1942, Whyte's immersive study of the Italian neighborhood in 1943 and Sutherland's study of white collar crime in 1949. The second Chicago School followed this same logic and increased the immersive situations, for example, with Becker studying marijuana smokers, Goffman studying mental health patients in asylums and Straus studying those in hospitals. Alinsky, Dolci, McClung Lee and even Wacquant and Weber also conducted significant works on other continents, in other eras and in other, very different social spheres. This second Chicago school is described as interventionist by Blumer because it is interested in the individual who acts according to the meaning he gives to his action. In a negotiated social order (Strauss), this meaning is modified by the interaction with other individuals and by the individual cognitive process.

Faced with a sociology that was thought of as too academic, the Chicago School showed its uniqueness. Its pragmatism and empirical awareness made up its intrinsic identity. However, some will criticize it, like intervention sociology in general, for its approach too localized and detached from any spatio-temporal framework (Giddens, 1983). This way of perceiving the discipline of sociology as closely as possible to social individuals, sometimes as actors, sometimes as agents and sometimes as subjects, was emulated in France. Therefore, the institutional analysis proposed in the 1970s by Loureau, Lapassade and Hess called for a critical analysis of the institution. It looked to shed light on the hidden institutional processes "of concealment, scotomization and repression" (Hess \& Authier, 1994, p. 78). According to the principle of the "tell all" rule, this was a matter of exposing the true life of the organization with its own codes and operating rules (which institutionalists refer to as "agorism" in contrast with "being cryptic" or the art of the secret). In order to do this, the researchers identified three elements in changing institutions. Established indicates that order and organization, law, measures, conventions, operating methods are in place. It has a general scope and is imposed on members. Establishing refers to transformation forces, reassessing the existing and contesting the norms and modalities of the established. For sociologists in this branch, that which is establishing has the ability to act on the established. As soon as there is a framework, norms and rules, there is a response to transgression, opposition and strategies for workarounds and resistance. A period of institutionalization then ensues, during which the body incorporates change, integrates it and creates new standards. The change driven by the established becomes a new means of operating that provides temporary stability before restarting a new cycle. "It is in creation and in production that man is seen as a historical subject" (Touraine, 1965, p. 133). With this phrase, Touraine presents his theory of actionalism as a means of analyzing human actions. It goes further than historicism (history is what defines man) and individualism (the individual makes history). By removing themselves from the nature over which they have increasing control, man becomes aware of their capacity for cultural creation. This does not change the fact that to understand it, their action must be studied as a product of individual and societal expression. The objective of Touraine's actionalism is to analyze social movements as an expression of man's actions in an effort to understand their historicity (Dubet \& Wieviorka, 2016). Sociological intervention is the method developed by the author to study these social movements. It invites the sociologist to "go into gray and silent areas instead of watching the city lights turn on" (Touraine, 1990, p. 526). Similarities can be found among advocates of strategic analysis. The key concepts can be summarized in the essential ideas of rationality, strategies and seizing opportunities, power and managing areas of uncertainty in a real system of action. For Crozier and Friedberg (1977), the individual is a subject (psychological approach), an agent (individual who carries out the actions and is the subject of study), but also an actor, meaning a rational and free individual. Individuals are perceived as rational beings who act, of course, in the collective interest, but also, and above all, in their personal interest. They participate in power struggles by acting in areas of uncertainty linked to their positions, their levels of expertise and to controlling formal and informal organizational rules. Therefore, rationales behind interests are outlined everywhere, sometimes converging, often diverging, which influences the strategies of actors. To highlight the "real systems of actions", strategic analysis offers a personal inductive approach. Morin explains that in recurrent reasoning, the product and producer are inextricably linked, to the extent that "the product is the producer of that which it produces" (Morin, 2005, p. 115). The principle of recursiveness, which we found in particular in Giddens' theory of structuring, implies that there are no unequivocal or unilateral relationships where each effect corresponds to a cause. Rather, recursiveness assumes that there are circular, looping relationships between the environment and the individual, between causes and consequences, between individuals and sociologists structured around a hermeneutic double that organizes the free circulation of knowledge and reciprocal influences. 


\section{Discussion of a comparative procedural methodology}

Regardless of the aforementioned branches of intervention (action research, socio-analysis, institutional analysis, sociological intervention, strategic analysis), each offers a complex approach made up of successive and precise steps (see the table below) that makes it possible to summarize "réalité chaude" (live reality), as highlighted by Hess (1981). According to Barbier (1996), Lewin's methodology of action research identifies three steps for analysis. Determining and contextualizing the problem is the first step. In most cases, the researchers respond to an explicit request. The relay group (the researchers) then try to contextualize the problems raised and to identify the needs expressed by the target group (actors in the field). The following step concentrated on planning and jointly building hypotheses for clarifying the problems discussed between the relay and target groups. To do this, the researcher carries out participative observation (active or complete), which means them becoming involved in the life of the group (they often take field notes). Lastly, the final stage is trying to theorize and evaluate the actions taken to resolve the problem. Action research is complete when the initial problem is solved. Dubost (2006) explains that for socio-analysis, the process related to the type of investigation carried out includes four steps: The informal initial contact makes it possible to evaluate the nature of the request and the organization's expectations. This is followed by the intervention, strictly speaking, and in particular recognition of the problem after creating a planning group that includes the consultant and actors in the organization. The pilot study then aims to make a list of and evaluate the techniques that are likely to resolve the problems faced. The last step is to carry out the project alongside all those concerned who discuss and regulate the different stages of implementation. Touraine's sociological intervention lasts for several dozen sessions and is characterized by the use of a first step known as self-analysis. Self-analysis seeks to lead the group (made of about a dozen people) to reflect on the meaning of their actions and carry out self-criticism (when this is achieved, the author speaks about conversion). The group analyst includes three researchers: The interpreter lives within the group and prompts awareness, while the secretary transcribes everything that they see. The analyst remains in the background, observing and analyzing the situation. The second step is interpretation. This consists of leading actors to interpret the social movement with support from sociologists. This back-and-forth forms a sort of continuous sociology between the authors and researchers. For advocates of strategic analysis, it is possible to distinguish three instances during the intervention. Firstly, it is a matter of adopting a position that takes a step back and creates a critical distance, making it possible to break with the sensitive reality and categories of common sense. Secondly, this concerns leaving the position of a detached and external observer to achieve "a turn to the inner character of actors" (Crozier \& Friedberg, 1977). The deep meaning of interpersonal relationships are not easily unveiled and this concerns going into the situation on the same level and putting themselves in the shoes of the actors in order to understand their internal rationales. This turn to the internal is necessarily contingent by temporarily eliminating any distance between the sociologist and the actors in the situation. It is only later (thirdly) that there is a need to again take up an external position by comparing and contrasting the several contingent rationalities and strategies observed. At this stage of the research, the strategic analysis sociologist looks to measure these gaps between that which should take place and the reality observed. By mobilizing a cumulative sociology (Mendras, 1975), they lean towards a progressive increase in generality, which takes place in particular by comparing the results of these different studies that focused on similar fields.

Table 1. The stages of intervention in the main sociological theories of intervention

\begin{tabular}{|c|c|c|c|}
\hline Action research LEWIN & $\begin{array}{l}\text { Socio-analysis } \\
\text { JAQUES }\end{array}$ & $\begin{array}{l}\text { Sociological intervention } \\
\text { TOURAINE }\end{array}$ & $\begin{array}{l}\text { Strategic analysis } \\
\text { CROZIER }\end{array}$ \\
\hline $\begin{array}{c}1 \\
\text { Contextualization }\end{array}$ & $\stackrel{1}{\text { Informal initial contact }}$ & $\begin{array}{c}1 \\
\text { Self-analysis (reflecting on the } \\
\text { meaning of the action) }\end{array}$ & $\begin{array}{c}1 \\
\text { Initial contact and passive } \\
\text { observation }\end{array}$ \\
\hline $\begin{array}{c}2 \\
\text { Planning and co-creating } \\
\text { hypotheses }\end{array}$ & $\begin{array}{c}2 \\
\text { Recognizing the problem }\end{array}$ & $\begin{array}{c}2 \\
\text { Interpreting the social } \\
\text { movement }\end{array}$ & $\begin{array}{l}2 \\
\begin{array}{l}\text { Immersion and practical } \\
\text { reasoning }\end{array}\end{array}$ \\
\hline $\begin{array}{c}3 \\
\text { Evaluating actions }\end{array}$ & $\begin{array}{c}3 \\
\begin{array}{c}\text { Pilot study (technical } \\
\text { tools for solving } \\
\text { problems) }\end{array} \\
-4 \\
\text { Carrying out project }\end{array}$ & $\begin{array}{c}3 \\
\text { Actors and researchers } \\
\text { (interpreter-sociologist-analyst) }\end{array}$ & $\begin{array}{l}3 \\
\text { Increase in generality and } \\
\text { theoretical reasoning }\end{array}$ \\
\hline
\end{tabular}


The sociological approach to intervention is described using "procedural science" (Friedberg, 1997, p. 321). As underlined by Crozier, the scientific nature of analyses is dependent on adhering to an investigation procedure that should guarantee collection and processing of data that is as open, systematic and honest as possible. For proponents of this sociological position, it is a matter of highlighting the scientific nature of the methodological procedures used.

The various stages and steps in the intervention process, as summarized above, bring together the main methodological procedures that characterize this branch of sociology. After a period of observation and maintained contact from a distance, the sociologist becomes immersed in a microsituation, as proximity to the group being studied intends to bring together the conditions for self-analysis. Using the Socratic method, this involves prompting actors to become aware of the need for change and their considerable involvement in the research into means of action. The Socratic method (maieutics) is a reference to Greek mythology. It recommends leading people to produce their knowledge spontaneously. In the same way as servitude implies a minimal desire to obey (La Boétie, 2016), the intervention's raison d'être lies within the individual's minimal desire to cooperate. Therefore, there has to be a real social demand (the sponsor can be clearly identified or much more vague), which is essential to microsociological analysis. As for interdisciplinarity, it finds legitimacy in the receptiveness of intervention disciplines. In the 1980s, authors such as Hess (1981) had already recommended reconciling sciences by putting side-by-side sociological intervention, psychoanalysis, psychosociology and even ethnology. More recently, Gaulejac et al. (2012, p. 13) highlighted the benefit of revisiting the disciplinary boundaries between human sciences and social sciences. As confirmed by Mendras, "social science is one" and there is no "disciplinary imperialism", nor any uncrossable borders between social psychology and sociology (Mendras, 1975, p. 8).

\section{Conclusion}

Intervention sociologists call for the use of practical, empirical sociology in which intuitive qualities and inductive perspectives are offered to the social individual. Description is insufficient to do this. An explanation is necessary. The question of conceptualization is central to sociological intervention because it forms one of its main criticisms. Intervention sociologists are often faced with the critique of a theoretical weakness to the extent that they only keep the "immediate impacts" of the present experience (Hanique, 2012, p. 125). As Crozier acknowledges, the increase in generality that can be expected in all scientific approaches is not apparent to the researcher immersed in analyzing an organizational situation. Although conceptualization is not necessarily the purpose of the intervention (Crozier 2000), it reinforces its legitimacy by trying to highlight social consistencies that are likely to explain society as a whole using a series of case studies and comparisons. - kinds of "constant comparative analysis", write Glaser \& Strauss (1973). Of course, the knowledge produced by immersion in the context must be applicable and usable for individuals in the situation (this is, incidentally, the first objective mentioned by a number of researchers, such as Crozier and Friedberg), but Schnapper (2011) specifies that it is only one of the foundations on which the effort of intelligibility is based. Beyond that, it must be equally possible to place the organization or social group in a more global and generalized context that aims to bring out in-depth constants and trends. According to Coenen-Huther (2008), empirical teachings should thus make it possible to discover constants that the sociologist can then detach from the particular framework to raise it to the level of generalities. In his differentiation of the relationships for producing knowledge in context, Uhalde (2016) distinguishes self-diagnosis (for managing or HR), diagnosis by others (for the client system that sponsors the study) and lastly, diagnosis for research (for knowledge in general and the scientific community). Highlighting the different temporalities and objectives, which are sources of dilemmas and questions, Uhalde concludes that they are complementary. In terms of intervention, everything is therefore a question of objectives: short-term when it concerns a contingent request and, as indicated by Mendras, long-term when it concerns making sociology a cumulative science that gathers local observations that are likely to lead to social patterns in the long term.

\section{Reference}

Alinsky S. (1978). Manuel de l'animateur social. Paris : Seuil. Point. https://doi.org/10.2307/3321406

Arnault, F. (1984). Frédéric Le Play, de la métallurgie à la science sociale. Revue française de sociologie, 25(3), 437-457.

Barbier, R. (1996). La recherche-action. Paris : Anthropos. Collection ethno-sociologie.

Becker, H. (1985). Outsiders. Études de sociologie de la déviance. Paris: Métailié. https://doi.org/10.3917/meta.becke.1985.01

Bernardeau-Moreau, D. (2014). Sociologie d'intervention : historique et fondements. Revue européenne des sciences sociales, 52(2), 191-220. https://doi.org/10.4000/ress.2872

Blumer, H. (1969). Symbolic Interaction: perspective, and method. Prentice-Hall : Englewood Cliffs.

Bucolo, E., \& Haeringer, J. (2018). L'intervention sociologique en association, Sociologies pratiques, 1(36), 105-115. 
https://doi.org/10.3917/sopr.036.0105

Burgess, E., \& Park, R. (1921), Introduction to the science of sociology. Chicago: Illinois. University of Chicago Press.

Cabé, M.-H. (2016). Le sociologue intervenant à l'épreuve de l'intervention : l'art du déséquilibre et du contrepoint. Sociologies pratiques, 1 (HS 2), 117-128. https://doi.org/10.3917/sopr.hs02.0117

Chapoulie, J.-M. (2005). Un cadre d'analyse pour l'histoire des sciences sociales. Revue d'histoire des sciences humaines, 13, 99-126. https://doi.org/10.3917/rhsh.013.0099

Chapoulie, J.-M. (2012). Un regard rétrospectif sur un demi-siècle d'enquêtes empiriques dans la sociologie française. Education et sociétés, 2(30), 33-48. https://doi.org/10.3917/es.030.0033

Cheysson, E. (1896). Frédéric Le Play : l'homme, la méthode, la doctrine. Paris : Guillaumin.

Coenen-Huther, J. (2008). Pour une sociologie des formes. Revue européenne des sciences sociales, XL-VI(140), 67-83. https://doi.org/10.4000/ress.169

Collier, J. (1942). L'Indien dans une nation en temps de guerre. Les Annales de l'Académie américaine des sciences politiques et sociales, 29-35.

Cooley, C. (1909). Social Organization: A Study of the Larger Mind. New York: Charles Scribner's sons. https://doi.org/10.1037/14788-000

Cressey, G.-P. (2008). The Taxi-Dance Hall: A Sociological Study in Commercialized Recreation and City Life. University of Chicago Sociological Series: University of Chicago Press. https://doi.org/10.7208/chicago/9780226120546.001.0001

Crozier, M. (2000). À quoi sert la sociologie des organisations? Vers un nouveau raisonnement pour l'action. (Volume 2). Paris : Arslan.

Crozier, M., \& Friedberg, E. (1977). L'acteur et le système. Paris : Seuil. Points.

Dewey, J. (1993). Logique. La théorie de l'enquête. Paris : PUF. L'interrogation philosophique.

Dolci, D. (1957), Enquête à Palerme. Paris : Julliard. Les Temps modernes.

Du Bois W.-E.-B. (1899). The Philadelphia Negro: A Social Study. Philadelphia: University of Pennsylvania Press.

Dubet, F. (2001). Plaidoyer pour l'intervention sociologique. In D. Vranken and O. Kuty, La sociologie et l'intervention. Enjeux et perspectives (p. 89-110). Liège: De Boeck Université. Ouvertures sociologiques. https://doi.org/10.7202/1036289ar

Dubet, F., \& Wieviorka, M. (2016). L'intervention sociologique. Lien social et Politiques, 75, 38-45. https://doi.org/10.7202/1036289ar.

Dubost, J. (2006). Analyse sociale et sociologies d'intervention. Paris : L'Harmattan. Histoire.

Dubost, J., \& Lévy A. (2016). Recherche-action et intervention. In J. Barus-Michel, E. Enriquez and A. Lévy (dir.). Vocabulaire de psychosociologie. Références et positions (p.408-433). Paris: Érès. Questions de société. https://doi.org/10.3917/eres.barus.2016.01.0408

Emery, F., \& Trist, E. (1965). The causal texture of organizational environments. Human Relations, 18(1), 21-32. https://doi.org/10.1177/001872676501800103

Franck, R. (1981). Recherche-action, ou connaissance pour l'action ? Quelques points de repère et trois positions de principe. International Review of Community Development, (5), 160-165. https://doi.org/10.7202/1034890ar

Friedberg, E. (1997). Le Pouvoir et la Règle. Dynamique de l'action organisée (2è éd.). Paris : Seuil. Points-Essais.

Gaulejac, (de) V., Hanique, F., \& Roche, P. (dir.) (2012). La Sociologie clinique. Enjeux théoriques et méthodologiques Paris : Érès. Sociologie clinique.

Giddens, A. (1987). La Constitution de la société (2è éd.). Paris : PUF. Sociologies.

Giglione, R., \& Matalon, B. (1998). Les enquêtes sociologiques : théories et pratique. Paris: Armand Colin. Collection $\mathrm{U}$.

Glaser, B.-G., \& Strauss, A. (1965). Awareness of Dying. Chicago: Aldine Publishing Company.

Goffman, E. (1961). Asiles, Études sur la condition sociale des malades mentaux et autres reclus. Paris: Editions de Minuit. Sens commun.

Hanique, F. (2012). De la sociologie compréhensive à la sociologie clinique. In V. (de) Gaulejac, F. Hanique and P. 
Roche, La sociologie clinique. Enjeux théoriques et méthodologiques (p. 105-130). Paris: Érès. Sociologie clinique.

Heinich, N. (2012). Une ou plusieurs sociologies ?. SociologieS. https://doi.org/10.4000/sociologies.3792

Herreros, G. (2009). Pour une sociologie d'intervention. Toulouse : Érès. https://doi.org/10.3917/eres.herre.2009.01

Herreros, G. (2012). Vers des organisations réflexives : pour un autre management, Nouvelle revue de psychosociologie, 1(13), 43-58. https://doi.org/10.3917/nrp.013.0043

Hess, R. (1981). La Sociologie d'intervention. Paris : PUF. Le sociologue. https://doi.org/10.3917/puf.hessr.1981.01

Hess, R., \& Authier, M. (1994). L'Analyse institutionnelle. Paris : PUF.

Hess, R., \& Savaoye, A. (1993). Analyse institutionnelle. Paris : PUF. Que sais-je ?.

Jaques, E. (1955). Social System as a defense against Persecutory and Depressive Anxiety, New directions in Psychoanalysis. London: Tavistock Publication.

La Boétie, E. (2016). Discours de la servitude volontaire. Paris : GF. Philosophie.

Lapassade, G. (1996). Les Microsociologies. Paris : Anthropos.

Le Play, F. (1848). Descriptions des procédés métallurgiques employés dans le pays de Galles pour la fabrication du cuivre, et recherches sur l'état actuel et sur l'avenir probable de la production et du commerce de ce métal. Paris : Thunot et Cie.

Le Play, F. (2000). Instruction sur la méthode d'observation dite des mono-graphies de familles propres à l'ouvrage intitulé Les Ouvriers européens, Les Études sociales, 131-132, 203-220.

Le Plzy, F. (1881). La Constitution essentielle de l'humanité. Exposé des principes et des coutumes qui créent la prospérité ou la souffrance des nations. Tours : Marne.

Lewin, K. (1946). Action research and minority problems. Journal of Social Issues, 2(4), 34-46. https://doi.org/10.1111/j.1540-4560.1946.tb02295.x

Liu, M. (1997). Fondements et pratiques de la recherche-action. Paris : L'Harmattan. Logiques sociales.

Lourau, R. (1970). L'analyse institutionnelle. Paris : Les éditions de minuit. Collection Arguments.

Marx, K. (1859). Critique de l'économie politique (french édition 1972). Paris : Editions sociales.

Mc Clung Lee, A. (1966). Multivalent Man. New York: George Braziller.

Mead, G.-H. (1934). Mind, Self, and Society. Chicago: éd. Charles W. Morris. University of Chicago Press.

Mendras, H. (1975). Eléments de sociologie. Paris : Armand Collin. Collection U.

Morin, E. (2005). Introduction à la pensée complexe. Paris : Points. Essais.

Pages, M. (1968). La vie affective des groupes. Paris : Éditions Dunod. collection Organisation et sciences humaines.

Parent-Duchatelet, A. (2008). La Prostitution à Paris au XIXe siècle. (text presented and annotated by Alain Corbin). Paris: Seuil. Points-Seuil Histoire.

Petit, F. (1989). Introduction à la psychosociologie des organisations. Paris : Privat.

Resweber, J.-P. (1995). La recherche action. Paris : PUF. Que sais-je ?.

Savoye, A. (1979). Genèse de la sociologie d'intervention (Thèse de doctorat de troisième cycle de sociologie, Université Paris X). CEDIAS documentary resources.

Schnapper, D. (2011). L'expérience-enquête au Conseil constitutionnel. Réflexion sur la méthode. Sociologie, 3(2), 295-309. https://doi.org/10.3917/socio.023.0295

Schütz, A. (2008). Le chercheur et le quotidien. Paris : Méridiens Klincksieck.

Shaw, C., \& Mc Kay, H. (1942). Juvenile delinquency and urban areas. Chicago: University of Chicago Press.

Simmel, G. (2003). Le conflit. Paris: Circé-poche.

Simpon, P.-J. (1991). Histoire de la sociologie. Paris : PUF. Fondamental.

Singly, (de) F., Giraud, C., \& Martin, O. (2011). Nouveau manuel de sociologie. Paris, Armand Colin.

Small, A., Vincent, G. (1894). An introduction to the study of society. New York: Cincinnati. American Book Company.

Stonequist, V. E. (1961). The Marginal Man: A Study in Personality and Culture Conflict. New York: Charles Scribner's 
Sons, Russell \& Russell.

Strauss, A. (1992). La Trame de la négociation. Paris : L'Harmattan.

Sutherland, E. (1949). White collar crime. New York: Holt, Rinehart \& Winston.

Thomas, W. I., \& Volkart, E. H. (1951). Social behavior and personality: contributions of W.I. Thomas to theory and social research. New York: Social Science Research Council.

Thomas, W. I., \& Znaniecky, F. (1918). The Polish Peasant in Europe and America. Volume 1 \& 2: Primary-group organization. Boston: The Gorham Press. https://doi.org/10.2307/3706945

Thrasher, F. (1927). The Gang: A Study of Gangs in Chicago. Chicago: University of Chicago Press.

Touraine, A. (1965). Sociologie de l'action. Paris : Edition du Seuil.

Touraine, A. (1978). La Voix et le Regard: sociologie des mouvements sociaux. Paris : Seuil.

Tristan F. (1835). Nécessité de faire un bon accueil aux femmes étrangères. (edition presented and commented by Cuche D. (1988). Paris : L’Harmattan.

Uhalde, M. (2016). Les dilemmes de la posture d'intervention sociologique : une grille d'analyse. Sociologies pratiques, 1 (HS 2), 7-20.

Wacquant, L. (2001). Corps et âme. Carnets ethnographiques d'un apprenti boxeur. Marseille and Montréal : Agone. Comeau and Nadeau.

Weber, M. (1963). Le savant et le politique. Paris: Collection 10/18 Bibliothèque. https://doi.org/10.3917/sopr.hs02.0007

Wirth, L. (1928). The Ghetto. Chicago: Chicago University Press.

Worm, R. (1918). Philosophie des sciences sociales, II. Méthode des sciences sociales. Paris: Giard \& Brière.

Zorbaugh, H. W. (1926). The Urban Community. Chicago: Chicago University Press.

\section{Copyrights}

Copyright for this article is retained by the author(s), with first publication rights granted to the journal.

This is an open-access article distributed under the terms and conditions of the Creative Commons Attribution license (http://creativecommons.org/licenses/by/4.0/). 